\title{
Recent Saiga population crash in China highlights how conservation of migratory species can only succeed with international
}

\section{collaboration}

Zhigang Jiang, ${ }^{1,2}$ David Mallon, ${ }^{3,4}$ Marc Foggin,,${ }^{5,6}$ Chunwang Li, ${ }^{1,2}$ Shaopeng Cui, ${ }^{1,2}$ Yan Zeng, ${ }^{1}$ Xiaoge Ping ${ }^{1}$

1 Institute of Zoology, Chinese Academy of Sciences, Beijing, 100101, China

2 University of Chinese Academy of Sciences, Beijing, 100049, China

3 Antelope Specialist Group, Species Survival Commission, IUCN

4 Department of Biology, Chemistry and Health Science, Manchester Metropolitan University, Manchester, M1 5GD, UK

5 Institute of Asian Research, School of Public Policy and Global Affairs, University of British Columbia, Vancouver, BC, Canada

6 Plateau Perspectives, South Surrey, BC, Canada

Abstract

Saiga (Saiga tatarica) was extirpated in China. Since Mid-1980s, attempts have been made for revival the species in the country, however, only a breeding herd of Saiga was successfully established at Wuwei, Gansu, China. The reintroduced Saiga population experienced a bumpy growth. Then, the population collapsed following the catastrophe die-off in the Saiga ranging countries in Central Asia. After reviewing the population trend and conservation breeding of Saiga in China, we concluded that to establish a migratory species that needs vast range size like Saiga on central Asia steppe, an international collaboration is needed. We recommend China to ratify the CMS in order to facilitate international conservation efforts to restoring the species in its former range.

Keyword: Saiga, antelope, conservation breeding, reintroduction, Convention on Migratory Species (CMS) 
The Saiga (Saiga tatarica) is a wide-ranging transboundary migratory species of the Central Asian steppes that requires large areas of seasonally differentiated habitats and territories to fulfill its life cycle (Singh et al., 2011). Currently, Saiga survive only in remnant habitats in Kazakhstan, Russia, Mongolia, and Uzbekistan (Fig. 1). In recent years the Saiga population decreased dramatically following collapse of the USSR in 1991 (Lushchekina and Struchkov, 2001; Milner-Gulland et al., 2001), but subsequently rebounded after two decades of concerted efforts with collaborative international conservation. However, a sudden outbreak of hemorrhagic septicemia caused by bacterium Pasteurella multocida serotype B occurred in 2015, causing the death of more than 200,000 Saiga within a short period of time in Kazakhstan and Russia (Fereidouni et al., 2019). A further mass die-off of Saiga was reported in Mongolia in 2018 due to Peste des Petits Ruminants (PPR, Pruvot et al., 2020). This cluster of disease outbreaks has put the once hopeful recovery of Saiga in peril again. In China, Saiga became extinct in the mid- $20^{\text {th }}$ century due to land cover change and especially over-hunting (Wang et al., 2001). The Wuwei Endangered Wildlife Breeding Centre (WEWBC, Now Gansu Endangered Animal Research Center) was established in Gansu Province in 1987 by the former Ministry of Forestry (now the National Forestry and Grassland Administration former), and as captive breeding population of Saiga was established with introductions from San Diego Zoo, USA and Berlin Zoo, Germany in 1989 and 1990 (Cui et al, 2016). However, the population grew only slowly during the initial period of establishment. For their part, subsequent attempts to introduce Saiga from Kazakhstan (1991) and Russia (1997) to Xinjiang failed, largely due to high mortality resulting from the stress of long-distance transportation. Only two Saiga from a herd of 21 coming from Kazakhstan survived the translocation in 1991 and both later died. Of a herd of 30 Saiga relocated from Russia to Xinjiang, only one survived the long-distance movement and it was later sent to WEWBC in 1997 (Wang et al., 2001). The Saiga population in WEWBC has not recruited any new blood into the population in the two decades since that time. 
From the initial 11 Saiga that arrived in 1989-90, the Saiga population in WEWBC began to increase more substantially in the new millennium and the population size reached over 130 in 2013 . However, the population then crashed: first it declined due to bad weather in the winter of 2014 , then a disease broke out and drastically reduced the Saiga population to only 20 individuals in 2018 (Fig. 2). The population thus returned to its original size from the mid-1990s at the beginning of the reintroduction program and it is impossible to foresee how long the population will need to recover, in part because of the population's low genetic diversity.

Analyses of the mitochondrial DNA control region and microsatellites from 40 umbilical cord blood samples revealed that genetic diversity was 0.49 and only two haplotypes were found in the population (Zhao et al., 2013). The Saiga is recognized as prone to disease. The infectious disease caused by the blue-tongue virus, BTV, was detected in 4 Saiga brought from San Diego Zoo in 1989, and these were therefore put down at the quarantine stage. More recently, PPR virus is the suspected pathogen that likely caused the mass die-off of Saiga at WEWBC in 2018 (Fig. 2).

The case of Saiga in China raises a serious question: can an extirpated species recover on the basis of a single population, at a single locality? Although some instances such as reintroducing Père David's deer (Elaphurus davidianus) andP rzewalski's wild horse (Equus ferus) thus far appear successful in China (Jiang, 2016; Jiang and Zong, 2019), the Saiga case, on the other hand, has been fraught with setbacks. Wildlife management authorities in China have poured much financial and human resources into the project, maintaining a large conservation facility, developing a watering system and planting alfalfa for the reintroduced Saiga, along with the wide-ranging skills and efforts of dozens of management and professional staff including veterinarians working for WEWBC. Nevertheless, the population still crashed unexpectedly in 2018, over 25 years after the population's establishment. Perhaps the devastating crash in the Wuwei population is indicative that the Breeding Center is not suitable, in some geographic or ecological way, for successful breeding 
of Saiga (Cui et al., 2016). Presumably, a much larger site is needed to provide enough space for this highly endangered migratory species to move around. Several large nature reserves have been established in the Saiga's former range, such as the Mt. Kalamaili Nature Reserve (14,000 km²), Xinjiang Aibi Lake Nature Reserve $\left(2,600 \mathrm{~km}^{2}\right)$ and Xiaerxili Nature Reserve $\left(314 \mathrm{~km}^{2}\right)$. However, there are still no founder populations in any of these protected areas. We believe that it is now time to comprehensively review the case of Saiga in China. With only one breeding population in the country, 'all the eggs are in one basket' and the population remains at high risk of catastrophe even if crashed populations sometimes rebound.

At the CITES CoP 18 in Geneva, Switzerland in August of 2019, Saiga was once again the focus of attention for the international conservation community. Up-listing the Saiga in CITES Appendix I was proposed, but this was rejected as many parties considered that such an act could hinder the international conservation efforts with relocations of the species across international boundaries. We concur and recommend carefully considering the importance of conservation-focused relocations. The Saiga population crash in China highlights how conservation of migratory species cannot be achieved successfully by countries in isolation, with closed populations of low genetic diversity, no matter how much effort the country puts into their conservation action. We should instead mobilize all former and extant range countries and the international conservation community to work together on the inter-related biological, ecological and sociopolitical issues that are necessary to save the Saiga.

International collaboration is highly recommended. So far, China still is not a party of the Convention on the Conservation of Migratory Species of Wild Animals, also known as the Convention on Migratory Species (CMS) or the Bonn Convention, which has 129 parties around the world. We recommend China to ratify the CMS in order to facilitate international conservation efforts including relocations, to open cross-border Saiga migration routes and to implement or participate in transboundary protection projects, to diversify the genetic base of its own population, to prevent and 
to control the spread of infectious diseases both internally and across borders, and thus in all of these ways to contribute to establishing a robust, healthy international Saiga meta-population (Jiang, et al., 2020). International conservation expertise in many disciplines and strategic management plans are already available or currently in development through the Saiga Conservation Alliance, providing an established platform for collaboration and action. Furthermore, these proposed avenues for strengthening Saiga conservation may readily be embedded in the framework of China's outward-looking development programming and investments, in particular through the biodiversity-oriented and people-to-people pillars of the Belt and Road Initiative (BRI) (Lechner et al., 2018; Ascensão et al., 2018; Nandintsetseg et al. 2019). Likewise, the upcoming global attention on environmental issues and biodiversity targets at CBD 2020, which will be held in Kunming, China, may serve as unique opportunity to reflect on the role and indeed the necessity for effective, fruitful international collaborations for ecological and socially-sound conservation. Both the Saiga and the people living in its range countries stand to benefit.

\section{Acknowledgement}

We sincerely thank Dr. Zhanqiang Wen, Jianyou Zhao for their help during the field data collection. The study was supported by Basic Science Special Project of Ministry of Science and Technology of China (2013FY110300)

\section{References}

Ascensão F, Fahrig L, Clevenger AP, Corlett RT, Jaeger JAG, Laurance WF, Pereira HM. 2018. Environmental challenges for the Belt and Road Initiative. Nat. Sustain. 1: 206-209.

Cui S, Milner-Gulland EJ, Singh NJ., Chu H, Li C, ChenJ , and Jiang Z. 2017. Historical range, extirpation and prospects for reintroduction of saigas in China. Scientific Reports 7: 44200.

Fereidouni S, Freimanis GL, Orynbayev M, Ribeca P, Flannery J, King DP, Zuther S, Beer M, Höper D, Kydyrmanov A, Karamendin K, Kock R. 2019. Mass Die-Off of Saiga Antelopes, Kazakhstan, 2015. Emerg. Infect. Dis. 25:1169-1176.

Kock RA, Orynbayev M, Robinson S, Zuther S, Singh NJ, Beauvais W, Morgan ER, 
Kerimbayev A, Khomenko S, Martineau HM, Rystaeva V, Zamira O, Wolfs S, Hawotte F, Radoux J and Milner-Gulland EJ. 2018. Saigas on the brink: Multidisciplinary analysis of the factors influencing mass mortality events. Sci. $A d v .4$ : eaao2314.

Jiang Z, Zong H. 2019. Reintroduction of the Przewalsi's Horse in China: Status Quo and Outlook. Nature Conservation Research 2019(4) (Suppl. 2) 15-22.

Jiang Z. 2013. Re-introduction of Père David's deer "Milu" to Beijing, Dafeng \& Shishou, China PP.143-147. Soorae, P. S. (ed.). Global Reintroduction Perspectives: 2013. Further Case Studies from around the Globe. Gland, Switzerland: IUCN/SSC Reintroduction Specialist Group and Abu Dhabi, UAE: Environment Agency-Abu Dhabi. xiv + 282 pp.

Jiang Z, Zhang Z, Zhang R, Ma Z, Chu H, Li Y, Ding C, Zhao Y, Xu J, Ping X, Zeng Y, Cui S, Li N, Cao D, W S, Xu J, Qi Y, Li C. 2020. Ratifying Bonn Convention, promoting global conservation of migratory animals. Biodiversity Science doi: 10.17520/biods.2019379.

Lechner, AM, Chan FKS, Campos-Arceiz A, Biodiversity conservation should be a core value of China's Belt and Road Initiative. Nat. Ecol. Evol. 2018, 2, 408-409

Lushchekina AA, Struchkov A. 2001.The saiga antelope in Europe: once again on the brink? The Open Country 3:11-24.

Milner-Gulland EJ, Kholodova MV, Bekenov A, Bukreeva OM, Grachev Iu A, Amgalan L, Lushchekina AA. 2001. Dramatic declines in saiga antelope populations. Oryx 35: 340-345.

Nandintsetseg D, Bracis C, Olson KA, et al. 2019. Challenges in the conservation of wide-ranging nomadic species. J. Appl. Ecol. 56: 1916- 1926.

Pruvot M, Fine AE, Hollinger C, Strindberg S, Damdinjav B, Buuveibaatar B, Chimeddorj B, Bayandonoi G, Khishgee B, Sandag B, Narmandakh J, Jargalsaikhan T, Bataa B, McAloose D, Shatar M, Basan G, Mahapatra M, Selvaraj M, Parida S, Njeumi F, Kock R, Shiilegdamba E. 2020. Outbreak of Peste des Petits Ruminants among Critically Endangered Mongolian Saiga and Other Wild Ungulates, Mongolia, 2016-2017. Emerg. Infect. Dis. 26: 51-62.

Singh NJ, Grachev IAA, Bekenov B, Milner-Gulland EJ. 2010. Tracking greenery across a latitudinal gradient in central Asia-the migration of the saiga antelope. Diversity and Distributions 16, 663-675.

Wang D, Luo N, Gu J, and Zhang G. 1998. The introduction and domestication of Saiga (Saiga tatarica) in its original distribution area of China. Biodiversity Science 6: 309-311.

Zhao S, Xu C, Liu G, Liu S, Zhao C, Cui Y, Hu D. 2013. Microsatellite and 
mitochondrial DNA assessment of the genetic diversity of captive Saiga antelopes (Saiga tatarica) in China. Chinese Science Bulletin 58: 2163-2167.

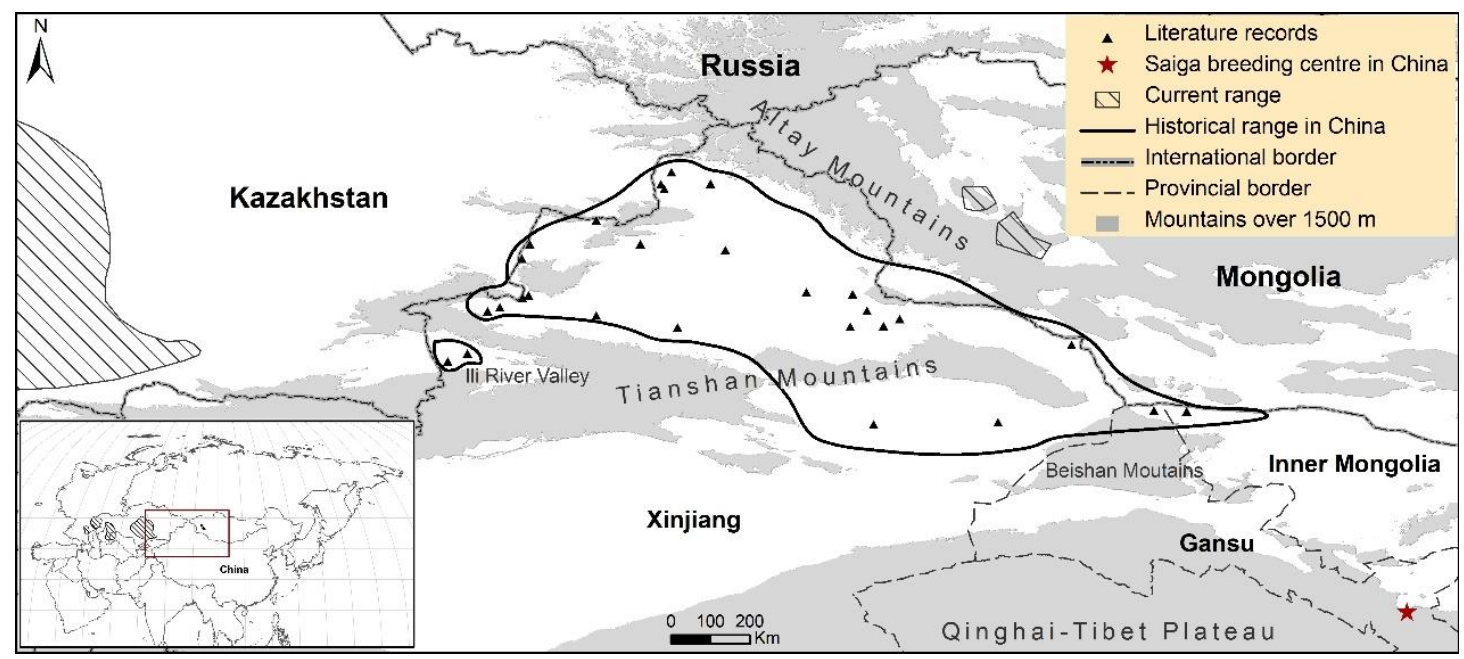

Fig. 1 Current distribution Saiga (Saiga tatarica).

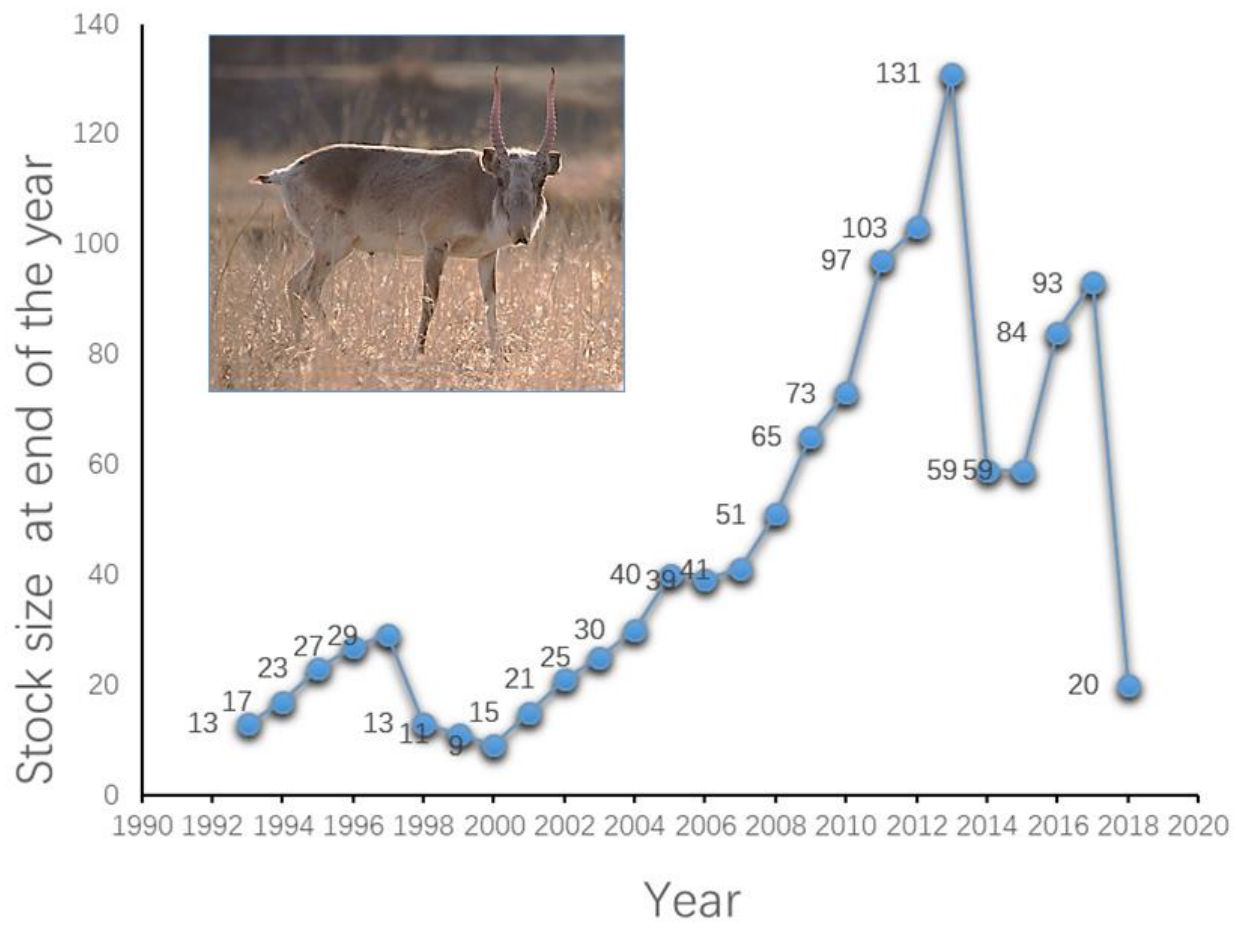

Fig. 2 The population of reintroduced Saiga at the Wuwei Endangered Species Breeding Centre, Gansu, China 